\title{
Region-Specific Regulation of Transforming Growth Factor $\alpha$ (TGF $\alpha$ ) Gene Expression in Astrocytes of the Neuroendocrine Brain
}

\author{
Ying Jun Ma, ${ }^{1,2}$ Karin Berg-von der Emde, ${ }^{1}$ Melissa Moholt-Siebert, ${ }^{1}$ Diane F. Hill, ${ }^{1}$ and Sergio R. Ojeda' \\ 'Division of Neuroscience, Oregon Regional Primate Research Center, Beaverton, Oregon 97006 and ${ }^{2}$ Department of \\ Physiology, Oregon Health Sciences University, Portland, Oregon 97201
}

\begin{abstract}
Certain glial cells of the hypothalamus have been implicated in the neuroendocrine control of reproductive development. Hypothalamic astrocytes appear to exert this function via a cell-cell interactive mechanism that involves the production of transforming growth factor $\alpha$ (TGF $\alpha$ ), a polypeptide able to affect both glial and neuronal functions in the CNS. In the hypothalamus, TGF $\alpha$ stimulates neuronal secretion of luteinizing hormone-releasing hormone (LHRH), the neuropeptide controlling sexual development, via activation of epidermal growth factor receptors (EGFR). Since astrocytes but not LHRH neurons express EGFR, it has been postulated that the stimulatory effect of TGF $\alpha$ on LHRH release is not exerted directly on LHRH neurons, but rather via glial intermediacy. The present experiments were undertaken to define whether TGF $\alpha$ is able to exert paracrine/autocrine effects on isolated hypothalamic astrocytes, and to determine if estradiol-previously shown to increase TGF $\alpha$ mRNA levels in the hypothalamus of immature animals - can act directly on hypothalamic astrocytes to upregulate TGF $\alpha$ gene expression. Treatment with either TGF $\alpha$ or its structural homolog, epidermal growth factor (EGF), increased TGF $\alpha$ mRNA levels within $8 \mathrm{hr}$ of exposure; the phorbol ester 12- 0 -tetradecanoyl-phorbol-13-acetate (TPA) was similarly effective. Blockade of EGFR with either tyrphostin RG-50864, an inhibitor of tyrosine kinase activity, or a monoclonal antibody that prevents ligand binding abolished the upregulatory effect of TGF $\alpha$ on TGF $\alpha$ mRNA levels. In contrast to hypothalamic astrocytes, cerebellar astrocytes did not respond to either TGF $\alpha$ or EGF with changes in TGF $\alpha$ mRNA abundance. This lack of response was not due to an absence of EGFR in cerebellar glia, as astrocytes from both brain regions were found to have similar levels of EGFR mRNA, and respond to TGF $\alpha$ or EGF with a similar change in EGFR autophosphorylation. Hypothalamic, but not cerebellar, astrocytes express the estrogen receptor (ER) gene and respond to estradiol with increased TGF $\alpha$ mRNA levels. This effect of estradiol was prevented by blockade of EGFR. The results provide evidence for the concept that TGF $\alpha$ can act in a paracrine/ autocrine manner to upregulate its own gene expression in
\end{abstract}

\footnotetext{
Received Nov. 4, 1993; revised Mar. 14, 1994; accepted Mar. 24, 1994.

This work was supported in part by NIH Grants HD-25123, RR-00163, and HD-18185. This is publication 1914 of the Oregon Regional Primate Research Center, Beaverton, OR

Correspondence should be addressed to Sergio R. Ojeda, D.V.M., Division of Neuroscience, Oregon Regional Primate Research Center, 505 N.W. 185th Avenue, Beaverton, OR 97006.

Copyright (C) 1994 Society for Neuroscience $0270-6474 / 94 / 145644-08 \$ 05.00 / 0$
}

hypothalamic astrocytes, and indicate that such regulatory mechanism does not operate in the cerebellum, a region irrelevant to neuroendocrine control. Expression of the ER gene in hypothalamic astrocytes and the ability of estradiol to upregulate TGF $\alpha$ mRNA abundance in these cells, but not in cerebellar astrocytes, further suggest that some glial cells of the hypothalamus are molecularly and functionally specialized to subserve neuroendocrine reproductive functions.

[Key words: astrocytes, estrogen receptor, transforming growth factor $\alpha$, hypothalamus]

Transforming growth factor $\alpha$ (TGF $\alpha$ ) and its homolog epidermal growth factor (EGF), are produced in the CNS (Wilcox and Derynck, 1988; Kudlow et al., 1989; Lazar and Blum, 1992), where they appear to function as mitogenic and neurotrophic factors (Leutz and Schachner, 1981; Morrison et al., 1987; Anchan et al., 1991). Although both peptides interact with EGF receptors to exert their biological actions (Carpenter and Cohen, 1990; Massague, 1990), TGF $\alpha$ expression in brain is much greater than that of EGF (Lazar and Blum, 1992), suggesting that TGF $\alpha$ may be the predominant ligand for EGF receptors in nervous tissue.

In addition to their mitogenic and neurotrophic activities, TGF $\alpha$ and EGF may contribute to regulating differentiated brain functions. Within the neuroendocrine brain, TGF $\alpha$ has been shown to stimulate the release of LHRH, the neurohormone that controls sexual development, from nerve terminals projecting to the median eminence of the hypothalamus. The effect of TGF $\alpha$ is exerted via an EGFR-mediated, prostaglandin-dependent mechanism (Ojeda et al., 1990). Since both the TGF $\alpha$ and EGFR genes are expressed in glial cells (Leutz and Schachner, 1981; Wang et al., 1989; Fallon et al., 1990; Ma et al., 1992a), and LHRH neurons are devoid of EGFR (Ma et al., 1994), it has been suggested that TGF $\alpha$ contributes to regulating the secretory activity of this highly specialized group of neuroendocrine neurons via a paracrine/autocrine-mediated activation of glial function (Ojeda et al., 1990; Ma et al., 1992a). Ovarian steroids controlling LHRH secretion may participate in this process by increasing hypothalamic TGF $\alpha$ gene expression (Ma et al., 1992a). Because of this, and the reported regional heterogeneity of brain astrocytes (Shinoda et al., 1989), the present experiments were undertaken to evaluate the possibility that TGF $\alpha$ expression in hypothalamic astrocytes is regulated by an interactive, region-specific mechanism involving sex steroids and TGF $\alpha$ paracrine/autocrine effects.

A partial report of these findings has appeared (Ma et al., 1992b). 


\section{Materials and Methods}

Cell culture. Hypothalamic and cerebellar astrocytes were isolated from 1-2-d-old rats, as described by McCarthy and de Vellis (1980), utilizing a Stomacher 80 blender (Tekmar, Cincinnati, $\mathrm{OH}$ ) for the mechanical dissociation (Saneto and de Vellis, 1987). Following a 2 min dissociation at $80 \%$ power, the cell suspension was filtered first through a $230 \mu \mathrm{m}$ metal sieve (Bellco, Vineland, NJ) and then through a $130 \mu$ m nylon mesh filter (Nitex, Elmsford, NJ). After assessing cell viability by trypan blue exclusion, the cells were plated in T-75 culture flasks at a density of $15 \times 10^{6}$ viable cells per flask and cultured in Dulbecco's minimal essential (DME)/F12 medium (50:50) supplemented with $10 \%$ calf serum under an atmosphere of $5 \% \mathrm{CO}_{2}, 95 \%$ air at $37^{\circ} \mathrm{C}$. Upon reaching confluency ( $8-10 \mathrm{~d})$, contaminating cells were removed by first shaking the flasks at $250 \mathrm{rpm}$ for $6 \mathrm{hr}$, replacing the medium, and then shaking again for $18 \mathrm{hr}$. Thereafter, the astrocytes were replated in six-well plates at 800,000 cells/well, transferred to astrocyte defined medium (ADM) after reaching $80-90 \%$ confluence, and used for the experiments $48 \mathrm{hr}$ later. ADM consisted of DME/F12 medium supplemented with insulin $(50 \mu \mathrm{g} / \mathrm{ml})$ and putrescine $(100 \mu \mathrm{M})$. The cultures were more than $95 \%$ pure as assessed by the number of cells containing the astrocytic marker, glial fibrillary acidic protein (GFAP). After fixing the cells with 95\% methanol, $5 \%$ acetic acid $\left(10 \mathrm{~min}\right.$ at $\left.-20^{\circ} \mathrm{C}\right)$, GFAP was detected by immunohistochemistry using the avidin-biotin complex (ABC) method as recommended by Nilaver and Kozlowski (1989). The primary antibody (R77, kindly provided by Dr. L. Eng, Stanford University) was employed at a dilution of 1:2000. Biotinylated protein A (1:1000) was the second antibody. Following addition of the $\mathrm{ABC}$ complex, the reaction was developed with the electron donor 3 '-diaminobenzidine tetrahydrochloride (DAB). Oxidation of DAB was achieved by adding glucose oxidase, $\beta$-D-glucose and ammonium chloride to the DAB solution (Nilaver and Kozlowski, 1989); this results in a slow but steady generation of hydrogen peroxide (Nilaver and Kozlowski, 1989). Microglial contamination, detected by the cellular presence of nonspecific esterases (Koski et al., 1976), was minimal. Using the method of Koski et al. (1976), the cytoplasm of microglial cells develops a red coloration of granular aspect that results from the esterification of $\alpha$-naphthyl butyrate added to the cultures in the presence of hexazotized pararosaniline. Prior to the reaction, the cultures were fixed in $4 \%$ paraformaldehyde for $30 \mathrm{~min}$ at room temperature.

Treatments. After $2 \mathrm{~d}$ in ADM, the medium was replaced by fresh medium containing TGF $\alpha(50 \mathrm{ng} / \mathrm{ml})$, EGF $(50 \mathrm{ng} / \mathrm{ml})$, or TPA $(10 \mathrm{ng} /$ $\mathrm{ml}$ ) and the culture was continued for 4,8 , or $24 \mathrm{hr}$. At the end of each interval, the cells were collected for RNA extraction (see below). To determine if the effect of TGF $\alpha$ on its own gene expression requires the activation of EGFR, other cultures were simultaneously treated for 8 hr with TGF $\alpha$ and either tyrphostin RG-50864, a selective blocker of EGFR tyrosine kinase activity (Yaish et al., 1988), or monoclonal antibody 425 , which has becn shown to antagonize ligand-induced activation of EGFR, presumably by reducing the accessibility of the EGFR binding site(s) to the ligand (Murthy et al., 1990).

The ability of ovarian steroids to affect TGF $\alpha$ gene expression in astrocytes was examined using two different paradigms. In one of them, the cells were treated with $17 \beta$-estradiol or its inactive stereoisomer $17 \alpha$-estradiol $(1 \mathrm{nM}, 272 \mathrm{pg} / \mathrm{ml})$ for 4,8 , and $24 \mathrm{hr}$. In the other, the cells were first exposed to $17 \beta$-estradiol $(272 \mathrm{pg} / \mathrm{ml})$ for $48 \mathrm{hr}$ and then to progesterone $(50 \mathrm{ng} / \mathrm{ml})$ for 2 or $4 \mathrm{hr}$, in an attempt to reproduce in vitro the conditions found to cause an increase in hypothalamic TGF $\alpha$ mRNA levels in vivo (Ma et al., 1992a). The participation of EGFR in mediating the effect of $17 \beta$-estradiol on TGF $\alpha$ mRNA levels was assessed as before, by incubating the cells for $8 \mathrm{hr}$ in the presence of $17 \beta$ estradiol plus either RG-50864 or Mab 425.

RNA extraction. Total RNA was extracted using the procedure of Peppel and Baglioni (1990), which these authors optimized for the extraction of RNA from cultured cells.

Solution hybridization/RNase protection assays. The procedure used has been described in detail in previous publications (Hill et al., 1992; Ma et al., 1992a; Junier et al., 1993). Total RNA samples (3-5 $\mu \mathrm{g})$, dried by vacuum centrifugation, were hybridized overnight at $45^{\circ} \mathrm{C}$ in $30 \mu \mathrm{l}$ of assay buffer containing $80 \%$ formamide in $40 \mathrm{~mm}$ PIPES (piperazine- $N$, $N^{\prime}$-bis[2-ethanesulfonic acid]) $\mathrm{pH} 6.4,0.4 \mathrm{M} \mathrm{NaCl}, 1 \mathrm{~mm}$ EDTA, and $500,000 \mathrm{cpm}$ of either a TGF $\alpha$, EGFR, or estrogen receptor (ER) antisense RNA probe labeled with ${ }^{32}$ P-CTP. Prior to use, each probe was purified by polyacrylamide gel electrophoresis. When detecting TGF $\alpha$ or EGFR mRNA, the hybridization mixture also con-

\section{A}
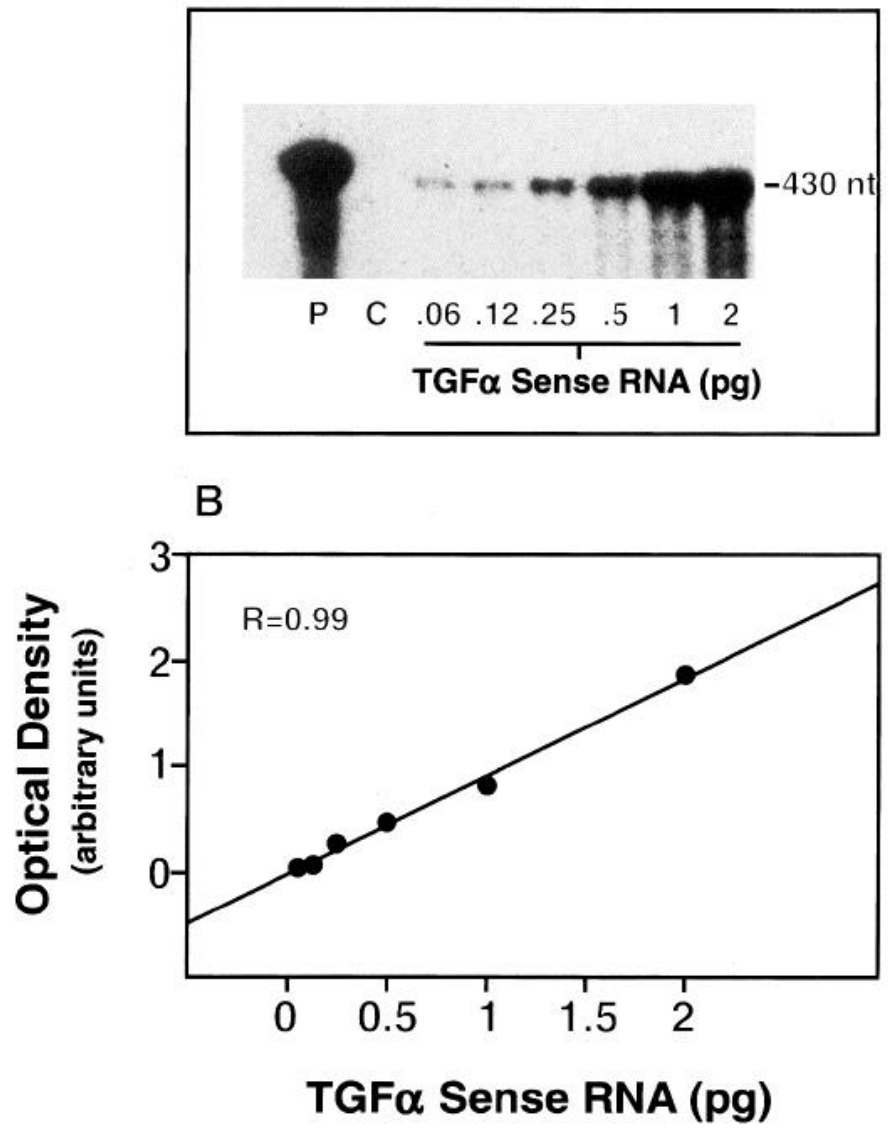

Figure 1. A, Standard curve of TGF $\alpha$ mRNA generated by hybridization of a ${ }^{32} \mathrm{P}$-labeled TGF $\alpha$ cRNA to increasing amounts of in vitro transcribed TGF $\alpha$ sense RNA followed by ribonuclease digestion. $P$, undigested probe; $C$, digested probe. $B$, Linear regression analysis for the standard curve depicted in $A$.

tained $5000 \mathrm{cpm}$ of a cyclophilin antisense RNA probe, which identifies the constitutively expressed cyclophilin mRNA (Danielson et al., 1988) and thus can be used to correct for procedural variability in the assay. We have previously validated the use of cyclophilin mRNA as an internal standard in the RNase protection assay by showing that, under conditions similar to those employed here, there is a linear relationship between the intensity of the hybridization signal and the amount of total RNA used (Junier et al., 1992). Following hybridization, the samples were treated with a mixture of ribonucleases $A$ and $T_{1}(40$ and $2 \mu \mathrm{g} /$ $\mathrm{ml}$, respectively) to digest nonhybridized RNA species, and the protected radiolabeled species were isolated by electrophoresis in a $5 \%$ polyacrylamide, $7 \mathrm{~m}$ urea gel. The hybridization signals were detected by exposing the dried gel to XAR-5 film. In the case of TGF $\alpha$ mRNA, the hybridization signals were quantitated using the computer analysis program Image (Correa-Rotter et al., 1992), compared to standard curves generated by hybridization of increasing amounts of in vitro transcribed sense TGF $\alpha$ mRNA to the TGF $\alpha$ probe (Fig. 1), normalized according to the cyclophilin mRNA signals, and expressed as fg RNA $/ \mu \mathrm{g}$ of total RNA. An edited version of the IMAGE program was obtained from Dr. Cary Mariash (University of Minnesota, MN). The program yields integrated optical densities following a user-specified method of subtraction of the background.

Probes. The antisense and sense TGF $\alpha$ RNA probes used correspond to the coding region of TGF $\alpha$ mRNA and were transcribed from a 400 base pair (bp) TGF $\alpha$ cDNA (Lee et al., 1985) cloned into the plasmid vector pGEM-3Z, as reported (Ma et al., 1992a). The EGFR cRNA probe spans the site of divergency between the full-length EGFR mRNA and the truncated EGFR mRNA form described to exist in rats (Petch et al., 1990). The 383 nucleotide (nt) probe recognizes $160 \mathrm{nt}$ of the sequence common to EGFR mRNA and its truncated form, and 223 
A
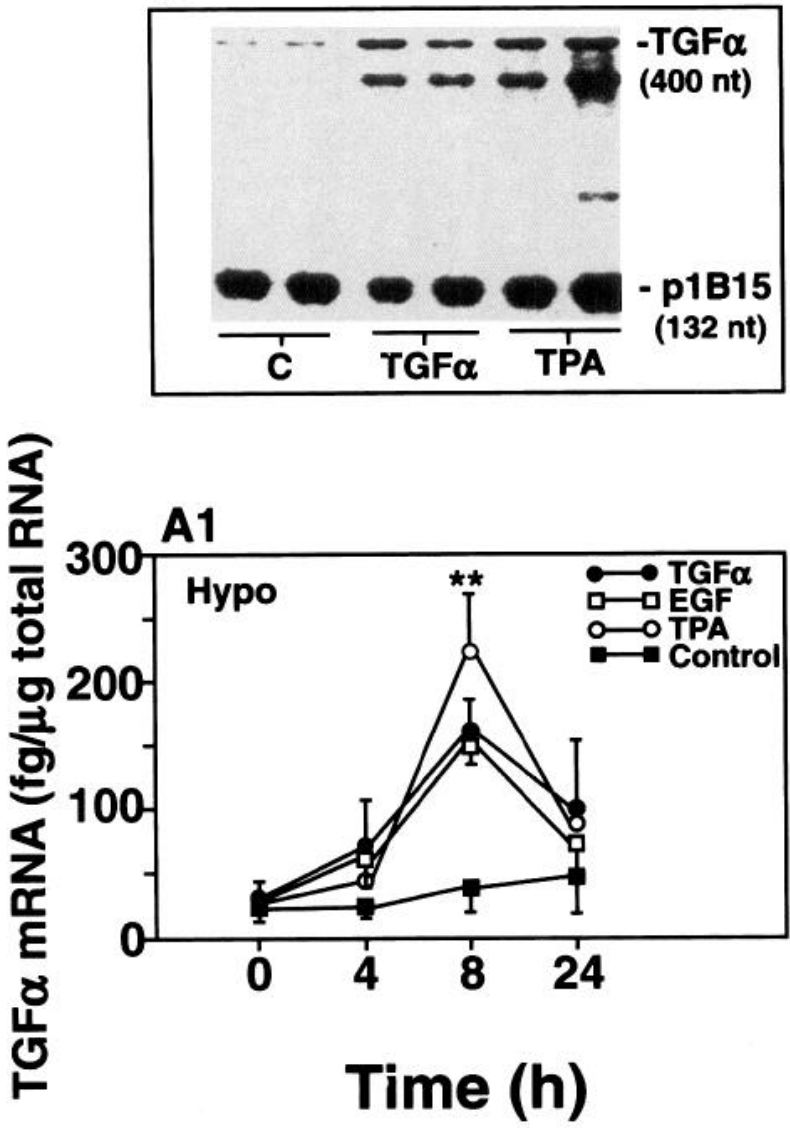

B

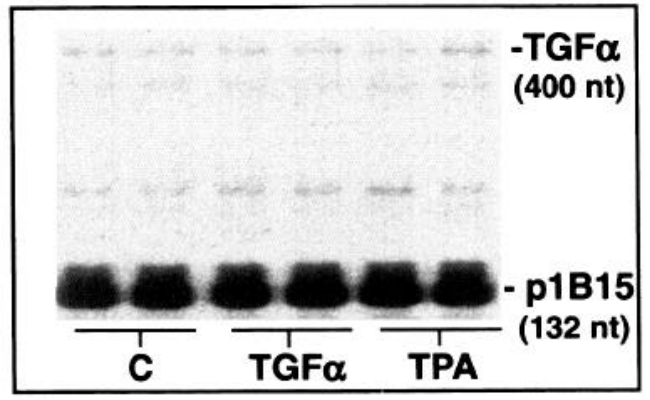

B1

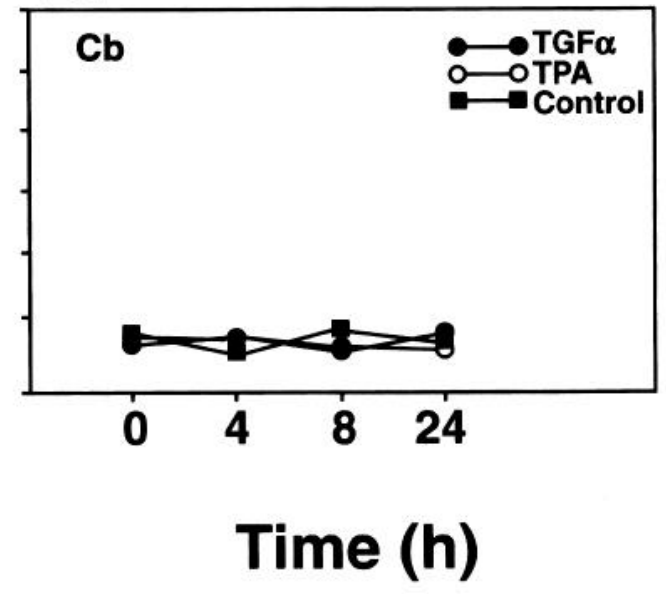

Figure 2. Ability of TGF $\alpha$ to increase its own gene expression in hypothalamic, but not cerebellar astrocytes in culture. A, Representative autoradiograms showing the effect of TGF $\alpha(50 \mathrm{ng} / \mathrm{ml})$ and TPA $(10 \mathrm{ng} / \mathrm{ml})$ on TGF $\alpha$ mRNA content of hypothalamic astrocytes, after $8 \mathrm{hr}$ of culture. AI, Quantitative data showing the time course of the effect of TGF $\alpha$, EGF, and TPA on hypothalamic astrocyte TGF $\alpha$ mRNA ievels. Each point represents the mean \pm SEM of six to eight culture wells. $B$, Representative autoradiogram illustrating the lack of effect of TGF $\alpha$ or TPA on cerebellar astrocyte TGF $\alpha$ mRNA levels. B1, Quantitative data showing the lack of changes in TGF $\alpha$ mRNA levels in cerebellar astrocytes after different times of exposure to TGF $\alpha$ or TPA. $C$, untreated control; $H y p o$, hypothalamus; $C b$, cerebellum. $p 1 B 15$, cyclophilin mRNA. ${ }^{* *}, p$ $<0.01$ versus controls, as determined by one-way analysis of variance followed by Student-Neuman-Keuls test.

nt specific to the $3^{\prime}$ end of the truncated EGFR mRNA species. Additional details concerning this probe have been reported (Junier et al., 1993). The cyclophilin cRNA probe used has also been described earlier (Junier et al., 1991). ER mRNA was detected using a cRNA transcribed from a 850 bp Xba 1-EcoR1 cDNA cloned into pGEM-3Z (Koike et al., 1987).

EGFR kinase assay. Confluent purified astrocytes, maintained in DME/ F12 medium with $10 \%$ calf serum in $100 \mathrm{~mm}$ dishes, were incubated with $1 \mu \mathrm{M}$ TGF $\alpha$ or EGF for $15 \mathrm{~min}$ at $37^{\circ} \mathrm{C}$ or were left untreated. The cells of each dish were solubilized in $0.75 \mathrm{ml}$ phosphate-buffered saline (PBS) containing $10 \%$ glycerol and $1 \%$ Triton X-100. After $1 \mathrm{hr}$ on ice, samples were microcentrifuged and the supernatant analyzed for protein content, using the Bio-Rad (Hercules, CA) method with bovine serum albumin (BSA) standards. The samples were stored at $-85^{\circ} \mathrm{C}$. Kinase reactions were initiated in room temperature samples, which contained $0.5 \mathrm{mg}$ protein in $0.5 \mathrm{ml}$, by adding $50 \mu \mathrm{l}$ of a cocktail that brought each sample to $10 \mathrm{~mm}$ HEPES pH 7.4, $1 \mathrm{~mm} \mathrm{Na} \mathrm{VO}_{4}, 1 \mathrm{~mm} \mathrm{MnCl}_{2}$, and $10 \mu \mathrm{M}$ ATP. After $7 \mathrm{~min}$, the kinase reaction was terminated by the addition of $20 \mathrm{~mm}$ EDTA. Anti-phosphotyrosine antibodies conjugated to agarose (Sigma Chemicals, St. Louis, MO) were employed to immunoprecipitate phosphorylated EGFR. Following electrophoresis on a $7 \%$ SDS polyacrylamide minigel, the separated proteins were blotted onto nitrocellulose. After blocking for $1 \mathrm{hr}$ with $2 \%$ BSA in Trisbuffered saline, the blot was probed with a monoclonal antiphosphotyrosine antibody (4G10, kindly provided by Dr. David Kaplan, Frederick Cancer Research and Development Center, Frederick, MD), then with an anti-mouse HRP-linked antibody (Boehringer-Mannheim, Indianapolis, IN). Phosphorylated species were detected using the
Amersham's (Arlington Heights, Il) enhanced chemiluminescence (ECL) system and XAR-5 film for autoradiography.

Statistics. The results were analyzed with a one-way analysis of variance and the Student-Neuman-Keuls multiple comparison test for unequal replications.

\section{Results}

The RNase protection assay employed to quantitate TGF $\alpha$ mRNA had a sensitivity of at least $60 \mathrm{fg}$ (the smallest amount of TGF $\alpha$ sense RNA used) and a linear range of detection that extended from $60 \mathrm{fg}$ to $2 \mathrm{pg}$ of TGF $\alpha$ mRNA (Fig. 1).

Hypothalamic astrocytes responded to both TGF $\alpha$ and EGF with an increase in TGF $\alpha$ mRNA abundance (Fig. 2). This increase was apparent within $4 \mathrm{hr}$ of exposure to either factor and reached maximal values by $8 \mathrm{hr}$; at $24 \mathrm{hr}$, TGF $\alpha$ mRNA levels approached control values. The time course of these changes was similar to that seen after treatment with TPA (Fig. $2 A, A 1)$, an activator of protein kinase $\mathrm{C}$ known to enhance $\mathrm{TGF} \alpha$ gene expression in other cell systems (Pittelkow et al., 1989). No such changes were observed in the levels of cyclophilin mRNA, which is constitutively expressed in brain (Danielson et al., 1988). In marked contrast, cerebellar astrocytes failed to respond to either $\mathrm{TGF} \alpha, \mathrm{EGF}$, or TPA with a change 
A
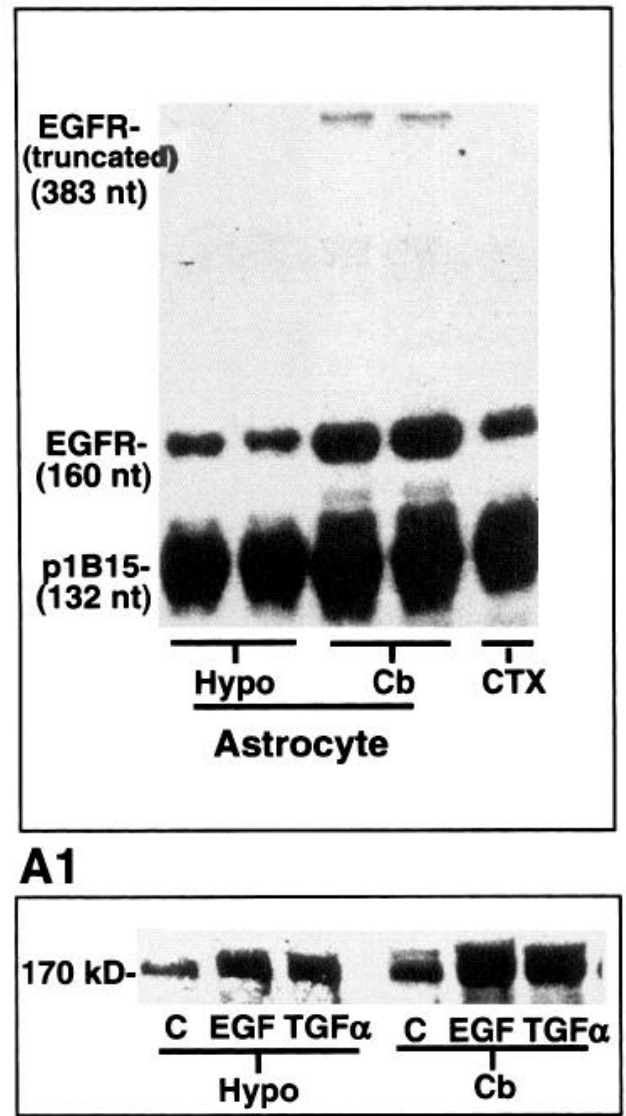

B
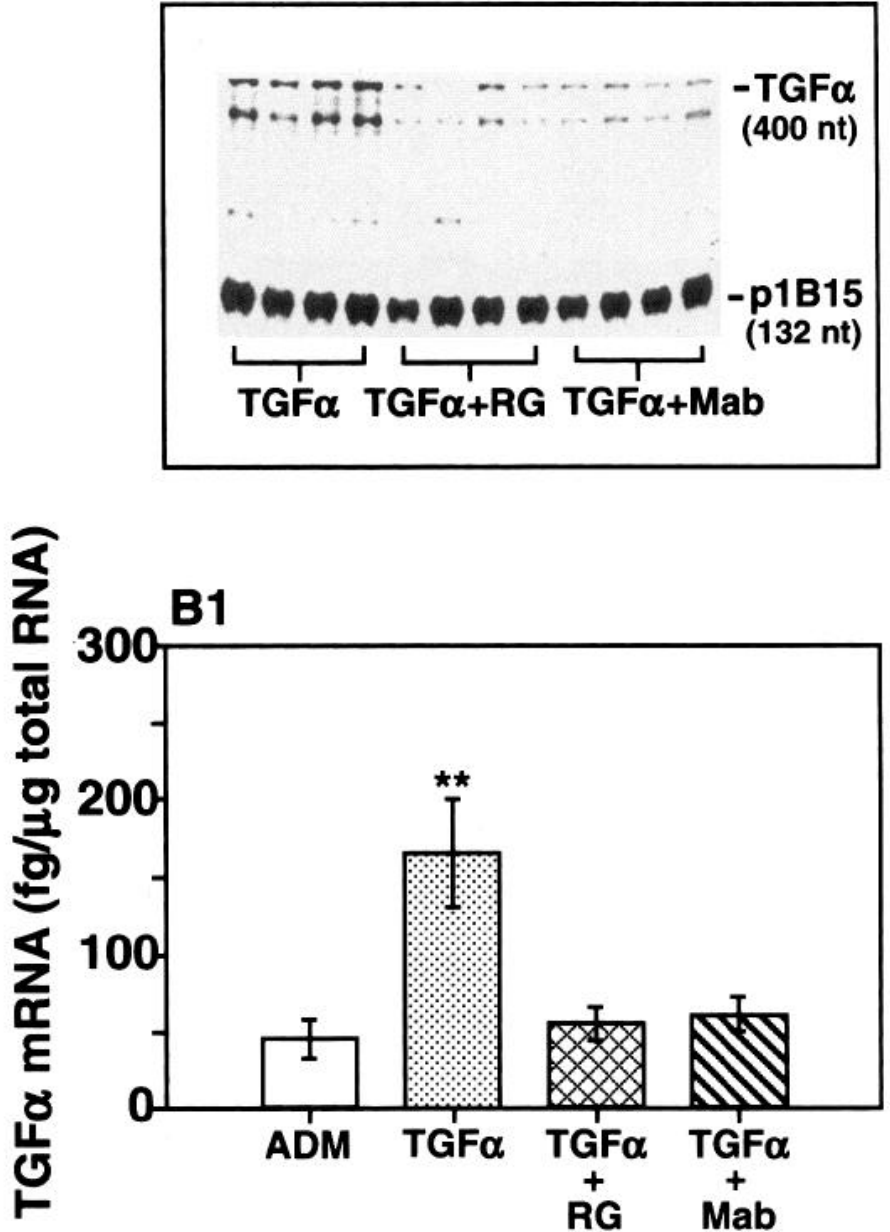

B1

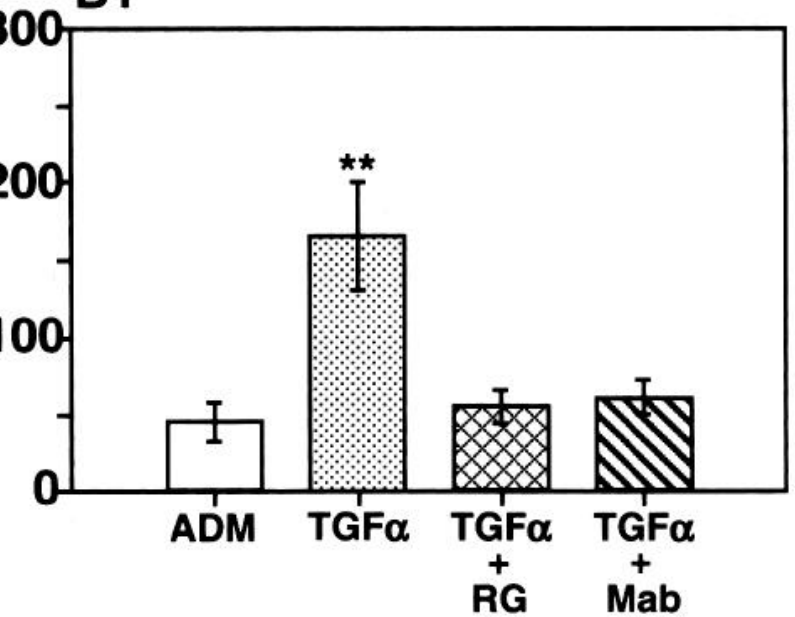

Treatments

Figure 3. A, Detection of EGFR mRNA in hypothalamic ( $\mathrm{Hypo})$ and cerebellar $(\mathrm{Cb})$ astrocytes, using an EGFR cRNA probe spanning the site of divergency between the mRNAs encoding the full-length EGFR and its truncated form (see Materials and Methods). The $160 \mathrm{nt}$ mRNA form corresponds to the extracellular domain encoding region of EGFR mRNA. The $383 \mathrm{nt}$ protected species corresponds to the truncated EGFR mRNA form that results from alternative splicing of the EGFR mRNA primary transcript in rats (Petch et al., 1990); CTX, cerebral cortex, whole tissue. A1, Ability of hypothalamic and cerebellar astrocytes to respond to TGF $\alpha$ or EGF stimulation (1 $\mu \mathrm{M})$ with increased EGFR autophosphorylation; $C$, control. $B$. Autoradiogram illustrating the ability of a blocker of EGFR tyrosine kinase $(R G, 60 \mu \mathrm{M})$ or a monoclonal antibody to the extracellular domain of EGFR $(M a b, 1 \mu \mathrm{g} / \mathrm{ml})$ to inhibit the increase in TGF $\alpha$ mRNA levels elicited by TGF $\alpha$ in hypothalamic astrocytes. B1, Quantitation of the data illustrated in $B$. Bars represent the mean \pm SEM of four independent observations per group. ${ }^{* *}, p<0.01$ versus all other groups. The cells cultured in ADM were exposed for $8 \mathrm{hr}$ to TGF $\alpha$ and the blockers.

in TGF $\alpha$ gene expression (Fig. 2B,BI). Unexpectedly, an additional TGF $\alpha$ mRNA species of about $350 \mathrm{nt}$ was detected in both hypothalamic and cerebellar astrocytes. This smaller species may be the product of alternative splicing events activated in cultured astrocytes, as it was barely detectable in vivo (Ma et al., 1992a). The abundance of this mRNA species changed in parallel to the changes in full-length TGF $\alpha$ mRNA content, suggesting that both forms are coregulated. In contrast, a minor band of about $180 \mathrm{nt}$ detected sporadically in hypothalamic astrocytes (Fig. $2 A$ ) or after longer film exposure in cerebellar astrocytes (Fig. 2B), may represent an assay artifact as its abundance was not correlated with treatment (see Figs. 2-4).

The ability of TGF $\alpha$ to upregulate its own gene expression in hypothalamic astrocytes appears to be mediated by EGFR and/ or a highly related receptor, as the effect of TGF $\alpha$ was abolished by either incubating the cells in the presence of tyrphostin RG-
50864, a blocker of EGFR tyrosine kinase activity (Yaish et al., 1988) or Mab 425, a monoclonal antibody that antagonizes ligand-induced activation of EGFR (Murthy et al., 1990) (Fig. $3 B, B 1)$. The lack of effect of TGF $\alpha$ on cerebellar astrocytes was not due to an absence of receptors because these cells were found to express the mRNAs encoding both the full-length EGFR and its truncated form (Petch et al., 1990) (Fig. 3A), and to respond to either TGF $\alpha$ or EGF with receptor autophosphorylation (Fig. $3 A 1)$.

Administration of $17 \beta$-estradiol to immature female rats, at doses that induce a precocious preovulatory surge of gonadotropins, increased TGF $\alpha$ mRNA in the anterior region of the hypothalamus. This effect was potentiated by the subsequent administration of an ovulatory dose of progesterone (Ma et al., 1992a). Hypothalamic astrocytes, which in vivo are composed of estradiol-sensitive and -insensitive cells (Langub and Watson, 
A
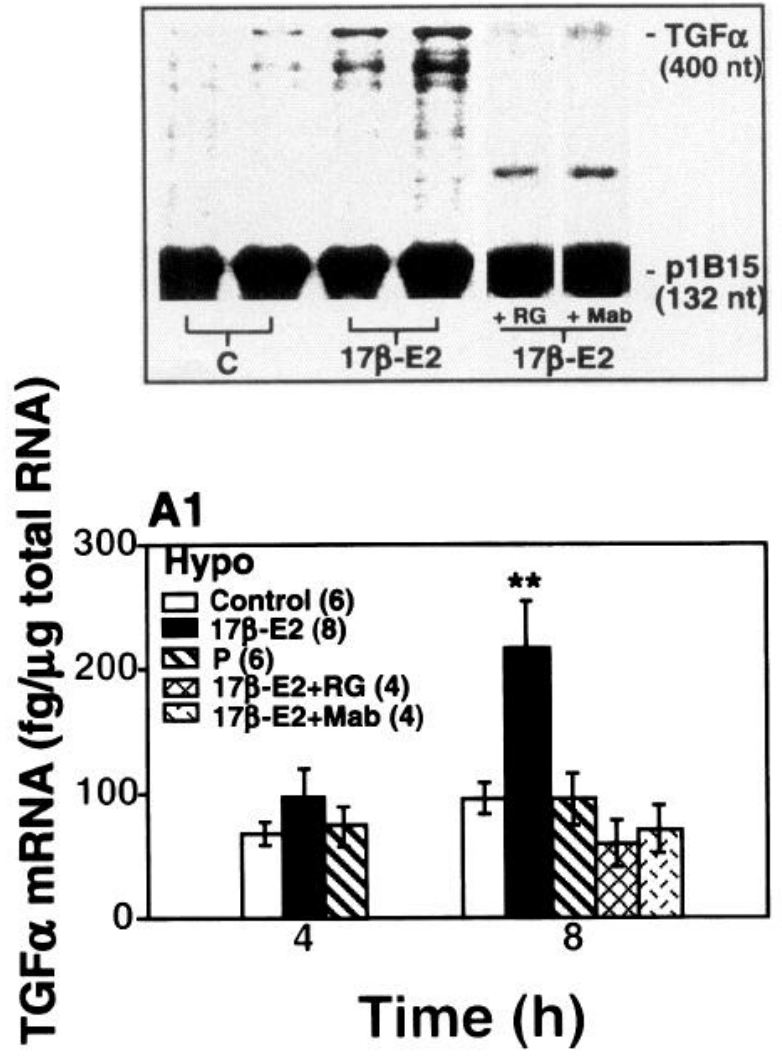

B

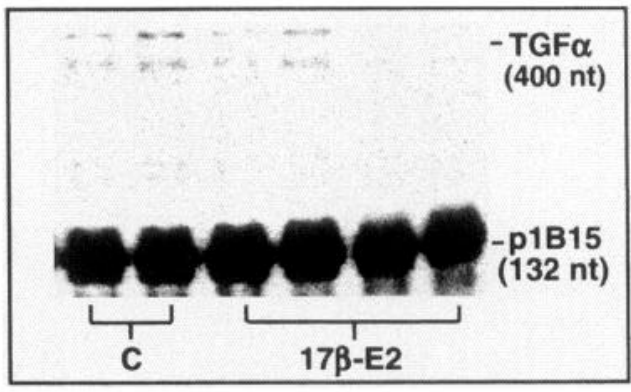

B1

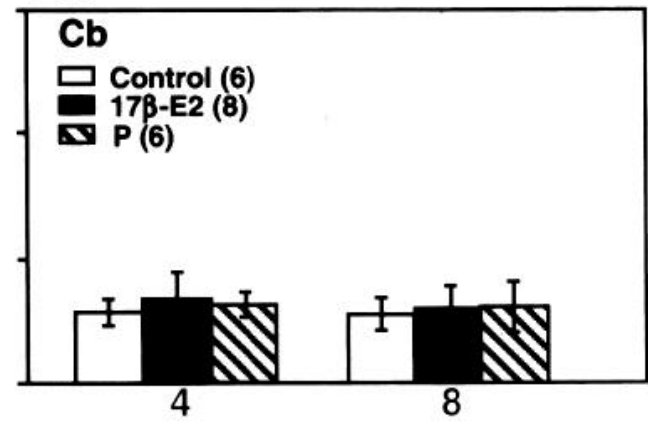

Time (h)

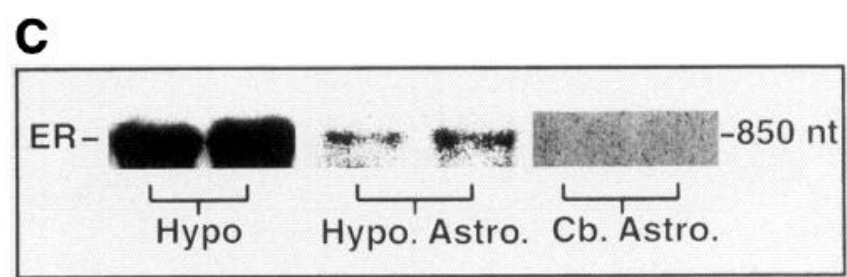

Figure 4. Upregulation of TGF $\alpha$ mRNA levels in hypothalamic astrocytes by $17 \beta$-estradiol $\left(17 \beta-E_{2}\right)$ is associated with selective expression of the estrogen receptor gene and requires activation of EGFR. $A$, Representative autoradiograph showing the increase in TGF $\alpha$ mRNA induced by $17 \beta$ $\mathrm{E}_{2}(272 \mathrm{pg} / \mathrm{ml})$ in hypothalamic astrocytes and the inhibition of this effect by a blocker of EGFR kinase $(R G, 60 \mu \mathrm{M})$ or a monoclonal antibody $(M a b, 1 \mu \mathrm{g} / \mathrm{ml}) . A l$ depicts the quantitated data for the experiments illustrated in $A$. The ineffectiveness of progesterone $(P, 50 \mathrm{ng} / \mathrm{ml})$ administered to cultures primed with estradiol $(272 \mathrm{pg} / \mathrm{ml}, 48 \mathrm{hr})$ is also shown. $B$ and $B 1$ show the inability of $17 \beta$ - $\mathrm{E}_{2}$ to affect TGF $\alpha$ gene expression in cerebellar astrocytes. $C$, Expression of the estrogen receptor $(E R)$ gene in hypothalamic, but not cerebellar astrocytes. Detection of ER mRNA in whole hypothalamus $($ Hypo $)$ is shown for comparative purposes. All lanes were loaded with $3 \mu \mathrm{g}$ of total RNA.

1992), responded to $17 \beta$-estradiol with a 2.5 -fold increase in TGF $\alpha$ mRNA levels 8 hr later (Fig. $4 A, A l$ ). No effect was observed at $4 \mathrm{hr}$. Progesterone added to the culture medium after priming the cells with estradiol for $48 \mathrm{hr}$, failed to change TGF $\alpha$ mRNA levels (Fig. 4A1). A similar ineffectiveness was observed in cerebellar astrocytes (Fig. $4 B 1$ ). The effect of $17 \beta$-estradiol on TGF $\alpha$ gene expression was region and stereospecific, as it was neither seen in cerebellar astrocytes (Fig. $4 B, B 1$ ) nor reproduced by its stereoisomer $17 \alpha$-estradiol in hypothalamic astrocytes $(47 \pm 11 \mathrm{fg}$ TGF $\alpha \mathrm{mRNA} / \mu \mathrm{g}$ total RNA in untreated controls vs $49 \pm 8 \mathrm{fg}$ in $17 \alpha$-estradiol-treated cultures, $n=6$ for each group). The regional specificity appears related to the selective presence of ER in hypothalamic astrocytes, as suggested by the presence of estrogen receptor mRNA in these cells (Fig. $4 C$ ).

Since only a subpopulation of hypothalamic astrocytes have estrogen receptors (Langub and Watson, 1992), it is possible that the estrogen effect in a mixed population of ER-positive and ER-negative astrocytes requires activation of TGF $\alpha / E G F$ paracrine actions for amplification. To examine this possibility, hypothalamic astrocytes treated with $17 \beta$-estradiol were simultaneously treated with RG-50864 or Mab 425. In both cases, the effect of estradiol on TGF $\alpha$ mRNA abundance was prevented (Fig. 4A).

\section{Discussion}

Although the physiological functions of astrocytes in the CNS are not fully understood, it is clear that they interact with neurons via cell-cell contacts and through humoral mechanisms (Lauder and McCarthy, 1986). In recent years, it has become clear that astrocytes are able to produce a variety of neuroactive substances and neurotrophic factors (Barres, 1991; Martin, 1992), suggesting that glial cells may play a more active role in neuronal 
regulation than has been previously thought. In addition, a growing body of evidence now exists indicating that astrocytes are phenotypically diverse, as they express different neuropeptide genes and neurotransmitter receptors in different brain regions (Stornetta et al., 1988; Lerea and McCarthy, 1989; Shinoda et al., 1989; Ernsberger et al., 1990). They also produce TGF $\alpha$ in a regionally diverse manner, as shown by the preferential expression of the peptide in astrocytes of the basal ganglia (Fallon et al., 1990), and in astrocytes of certain hypothalamic nuclei (Ma et al., 1992a).

The present results demonstrate that astrocytes of the neuroendocrine brain are molecularly and functionally distinct from astrocytes of the cerebellum, a region not involved in neuroendocrine control. Such a regional difference includes the ability of TGF $\alpha$ to upregulate its own gene expression via a paracrine/ autocrine mechanism, the ability of estradiol to utilize this mechanism to dircetly affect glial function without ncuronal intermediacy - and importantly - the expression of the estrogen receptor gene in hypothalamic astrocytes. Since only selected hypothalamic astrocytes appear to be targets of estrogen action (Langub and Watson, 1992), it is likely that estradiol acts directly only on astrocytes bearing estrogen receptors to enhance TGF $\alpha$ production. According to this concept, an initial step in the process by which estradiol upregulates TGF $\alpha$ gene expression in hypothalamic astrocytes would be a direct action on those astrocytes endowed with estrogen receptors. An incrcased production of TGF $\alpha$ in these astrocytes would then result in amplification of the estrogen signal, via a paracrine-dependent autoregulation of TGF $\alpha$ gene expression in astrocytes devoid of estrogen receptors. TGF $\alpha$, like other members of the EGF family, does not need to be released from its membrane-anchored precursor to exert its biological actions (Massague, 1990). Thus, an increase in TGF $\alpha$ production in a subset of astrocytes would suffice to activate $\mathrm{TGF} \alpha$ synthesis in adjacent glial cells via juxtacrine stimulation (Massague, 1990). This mode of action involves interaction of the mature TGF $\alpha$ peptide, still attached to its transmembrane precursor, with available EGFR located on adjacent cells (Massague, 1990). The results of the present study showing that blockade of EGFR prevents the increase in TGF $\alpha$ mRNA elicited by estradiol supports the overall validity of this concept. The potential relevance that such a cell-cell regulatory mechanism may have in the neuroendocrine control of sexual development is underscored by the recent finding that almost $50 \%$ of GFAP-immunopositive cells in the median eminence region of the hypothalamus are estrogen receptor positive (Langub and Watson, 1992). Glial cells of the median eminence, including astrocytes and tanycytes of the third ventricle, also express the TGF $\alpha$ and EGFR genes (Ma et al., 1992a, 1994), thus providing the opportunity for estrogen/TGF $\alpha$-mediated interactive events to occur. That an even more complex level of cross talk underlies the interaction of TGF $\alpha / \mathrm{EGF}$ and estrogen signaling pathways is indicated by the recent finding that both EGF and TGF $\alpha$ are able to induce transcriptional activation of an estrogen responsive element, via estrogen receptors, and that this activational effect is synergized by estradiol (IgnarTrowbridge et al., 1993). The existence of a similar complexity in hypothalamic astrocytes may help in explaining the surprising ability of EGFR blockade to abolish completely the effect of estradiol on TGF $\alpha$ mRNA levels, since no mediatory effect of EGFR would be expected in astrocytes bearing estrogen receptors. Another, simpler explanation is that the fraction of hypothalamic astrocytes expressing ER in vitro is much lower than the $50 \%$ observed in the median eminence in vivo (Langub and Watson, 1992). Under these very likely circumstances (only about $10 \%$ of glial cells are ER-positive in other hypothalamic regions (Langub and Watson, 1992), the inability of EGFR blockade to prevent the effect of E2 on TGF $\alpha$ mRNA levels in ER-bearing astrocytes would be very difficult to detect.

Within the neuroendocrine hypothalamus, a paracrine mode of control of glial TGF $\alpha$ gene cxpression may be important not only for the maturational process that leads to the first estrogeninduced preovulatory surge of I.HRH at puberty, but also as a cell-cell interactive mechanism contributing to the neuropathology of sexual precocity. This is suggested by the observation that while lesions of the hypothalamus leading to precocious puberty are associated with increased expression of both TGF $\alpha$ and EGFR in reactive astrocytes, the advancing effect of the lesion on puberty is prevented by blockade of EGFR tyrosine kinasc activity (Junier et al., 1991; Junier et al., 1993).

The present results do not offer an explanation for the unresponsiveness of cerebellar astrocytes to $\mathrm{TGF} \alpha$, despite the presence of biologically active EGF receptors. However, since cerebellar astrocytes also fail to respond to TPA, the defect might reside at a site of the biochemical cascade distal to the protein kinase C step. Alternatively, the autoregulatory actions of TGF $\alpha$ may not require protein kinase $C$ activation. It is known, however, that the cerebellum is essentially devoid of estrogen receptors (Pfaff and Keiner, 1973), which can explain the ineffectiveness of estradiol to alter TGF $\alpha$ mRNA abundance in astrocytes of this region.

Estradiol increases TGF $\alpha$ gene expression at various levels of the reproductive system (Adashi and Resnick, 1986; Skinner and Coffey, 1988; Mueller et al., 1989; Bates et al., 1990; Nelson et al., 1992); at least in humans, this effect may be exerted directly on TGF $\alpha$ gene transcription (Saeki et al., 1991). The 5' flanking region of the rat gene, on the other hand, does not appear to contain traditional estrogen responsive elements (EREs) (Blasband et al., 1990), suggesting that in this species estrogen actions on TGF $\alpha$ gene expression are either indirect or mediated by imperfect, but functional, palindromic ERE-like sequences (Blasband et al., 1990). In contrast to estradiol, the in vivo effect of progesterone on hypothalamic TGF $\alpha$ gene expression may not be directly exerted on astrocytes. It is possible that progesterone stimulates the production of neuronal molecules that interact with neighboring glial cells (Steward et al., 1991) to affect TGF $\alpha$ gene expression. Such molecules may be neurotransmitters for which glial cells express receptors (Murphy and Pearce, 1987; Bevan, 1990; Barres, 1991), or other not yet characterized bioactive substances (Steward et al., 1991). Alternatively, astrocytes in culture may require a long exposure to higher doses of estradiol to begin expressing progesterone receptors and become responsive to the steroid. It has been reported that cultured astrocytes exposed for 3-4 weeks to $50 \mathrm{~nm}$ estradiol develop biochemically and immunologically identifiable progcsterone receptors (Jung-Testas et al., 1991).

Taken altogether, these results suggest that the hypothalamus - a key component of the neuroendocrine brain - contains a subset of astroglial cells molecularly and functionally differentiated to perform functions requiring the interactive regulation of TGF $\alpha$ gene expression by autocrine/paracrine mechanisms and estrogen-dependent processes. Since hypothalamic astrocytes respond to $\mathrm{TGF} \alpha$ with release of prostaglandin $\mathrm{E}_{2}$ (Berg-von der Emde et al., 1993), a known LHRH secretagogue (Ojeda and Urbanski, 1988), it would appear that these inter- 
actions may contribute to the functional regulation of the neuronal circuitry that controls sexual development.

The present findings and the previous demonstration that glial cells are phenotypically diverse (Stornetta et al., 1988; Lerea and McCarthy, 1989; Shinoda et al., 1989; Ernsberger et al., 1990) strongly suggest that regional specialization of glial function may be a basic mechanism by which glial cells contribute to regulating the activity of discrete neuronal populations and/ or the response of a regionally segregated subset of innervated neurons. Such a fine specialization appears particularly evident in the case of the angiotensinogen gene, which is expressed in astrocytes associated with hypothalamic, midbrain, and brainstem nuclei, but not in astrocytcs outside these nuclei (Stornetta et al., 1988), and in the case of $\mathrm{TGF} \alpha$, which is preferentially found in astrocytes associated with certain hypothalamic nuclei (Ma et al., 1992a) and basal ganglia (Fallon et al., 1990). The ability of TGF $\alpha$ to upregulate its own gene expression in hypothalamic, but not cerebellar astrocytes, raises the possibility that the complex set of paracrine/autocrine regulatory loops controlling growth factor gene expression in glial cells (see, e.g., Spranger et al., 1990; Pons and Torres-Aleman, 1992) may also be regionally specialized.

Lastly, the ability of estradiol to increase TGF $\alpha$ gene expression in hypothalamic astrocytes suggests that this is an additional growth factor-mediated mechanism utilized by the steroid to regulate neuroendocrine neuronal function. Estradiol synergizes with insulin in promoting neurite outgrowth of hypothalamic explants in vitro (Toran-Allerand et al., 1988) and increases insulin-like growth factor I (IGF-I) receptor content in hypothalamic neurons without affecting either neuronal or glial production of IGF-I (Pons and Torres-Aleman, 1993). Thus, it is possible that at least some of the biological effects of estradiol on the neuroendocrine brain involve the concerted interaction of growth factors of glial and/or neuronal origin such as TGF $\alpha$ and IGF-I.

\section{References}

Adashi EY, Resnick CE (1986) Antagonistic interactions of transforming growth factors in the regulation of granulosa cell differentiation. Endocrinology 119:1879-1881.

Anchan RM, Reh TA, Angello J, Balliet A, Walker M (1991) EGF and TGF- $\alpha$ stimulate retinal neuroepithelial cell proliferation in vitro. Neuron 6:923-936.

Barres BA (1991) New roles for glia. J Neurosci 11:3685-3694.

Bates SE, Valverius EM, Ennis BW, Bronzert DA, Sheridan JP, Stampfer MR, Mendelsohn J, Lippman ME, Dickson RB (1990) Expression of the transforming growth factor- $\alpha$ /epidermal growth factor receptor pathway in normal human breast epithelial cells. Endocrinology 126: 596-607.

Berg-von der Emde K, Ma YJ, Costa ME, Ojeda SR (1993) Hypothalamic astrocytes respond to transforming growth factor alpha $(\mathrm{TGF} \alpha)$ with prostaglandin $\mathrm{E}_{2}\left(\mathrm{PGE}_{2}\right)$ release. Soc Neurosci Abstr 19: 1682.

Bevan S (1990) Ion channels and neurotransmitter receptors in glia. Semin Neurosci 2:467-481.

Blasband AJ, Rogers KT, Chen X, Azizkhan JC, Lee DC (1990) Characterization of the rat transforming growth factor alpha gene and identification of promoler sequences. Mol Cell Biol 10:2111-2121.

Carpenter G, Cohen S (1990) Epidermal growth factor. J Biol Chem 265:7709-7712.

Correa-Rotter R, Mariash CN, Rosenberg ME (1992) Loading and transfer control for Northern hybridization. Biotechniques 12:154 158.

Danielson PE, Forss-Petter S, Brow MA, Calavetta L, Douglass J, Milner RJ, Sutcliffe JG (1988) plB15: a cDNA clone of the rat mRNA encoding cyclophilin. DNA 7:261-267.

Ernsberger P, Iacovitta L, Reis DJ (1990) Astrocytes cultured from specific brain regions differ in their expression of adrenergic binding sites. Brain Res 517:202-208.

Fallon JH, Annis CM, Gentry LE, Twardzik DR (1990) Localization of cells containing transforming growth factor- $\alpha$ precursor immunoreactivity in the basal ganglia of the adult rat brain. Growth Factors 2:241-250.

Hill DF, Dissen GA, Ma YJ, Ojeda SR (1992) Detection of nerve growth factor and one of its receptors. In: Methods in neurosciences, Vol 9, Gene expression in neural tissues (Conn PM, ed), pp 179-196. New York: Academic.

Ignar-Trowbridge DM, Teng CT, Ross KA, Parker MG, Korach KS, McLachlan JA (1993) Peptide growth factors elicit estrogen receptor-dependent transcriptional activation of an estrogen-responsive element. Mol Endocrinol 7:992-998.

Jung-Testas I, Renoir JM, Gasc JM, Baulieu EE (1991) Estrogeninducible progesterone receptor in primary cultures of rat glial cells. Exp Cell Res 193:12-19.

Junier M, Ma YJ, Costa ME, Hoffman G, Hill DF, Ojeda SR (1991) Transforming growth factor alpha contributes to the mechanism by which hypothalamic injury induces precocious puberty. Proc Natl Acad Sci USA 88:9743-9747.

Junier M, Wolff A, Hoffman GE, Ma YJ, Ojeda SR (1992) Effect of hypothalamic lesions that induce precocious puberty on the morphological and functional maturation of the luteinizing hormonereleasing hormone neuronal system. Endocrinology 131:787-798.

Junier M, Hill DF, Costa ME, Felder S, Ojeda SR (1993) Hypothalamic lesions that induce female precocious puberty activate glial expression of the epidermal growth factor receptor gene: differential regulation of alternatively spliced transcripts. J Neurosci 13:703-713.

Koike S, Sakai M, Muramatsu M (1987) Molecular cloning and characterization of rat estrogen receptor cDNA. Nucleic Acids Res 15: 2499-2513.

Koski IR, Poplack DG, Blaese RM (1976) A nonspecific esterase strain for the identification of monocytes and macrophages. In: In vitro methods in cell mediated and tumor immunity (Bloom BR, David $R$, eds), pp 359-362. New York: Academic.

Kudlow JE, Leung AWC, Kobrin MS, Paterson AJ, Asa SL (1989) Transforming growth factor- $\alpha$ in the mammalian brain. J Biol Chem 264:3880-3883.

Langub MC Jr, Watson RE Jr (1992) Estrogen receptor-immunoreactive glia, endothelia, and ependyma in guinea pig preoptic area and median eminence: electron microscopy. Endocrinology 130:364 372.

Lauder J, McCarthy K (1986) Neuronal-glial interactions. In: Astrocytes, Vol 2 (Fedoroff S, Vernadakis A, eds), pp 295-314. New York: Academic.

Lazar LM, Blum M (1992) Regional distribution and developmental expression of epidermal growth factor and transforming growth factor- $\alpha$ mRNA in mouse brain by a quantitative nuclease protection assay. J Neurosci 12:1688-1697.

Lee DC, Rose TM, Webb NR, Todaro GJ (1985) Cloning and sequence analysis of a cDNA for rat transforming growth factor- $\alpha$. Nature 313 : 489-491.

Lerea LS, McCarthy KD (1989) Astroglial cells in vitro are heterogeneous with respect to expression of the $\alpha_{\mathrm{l}}$-adrenergic receptor. Glia 2:135-147.

Leutz A, Schachner M (1981) Epidermal growth factor stimulates DNA synthesis of astrocytes for primary cerebellar cultures. Cell Tissue Res 220:393-404.

Ma YJ, Junier M, Costa ME, Ojeda SR (1992a) Transforming growth factor alpha (TGF $\alpha$ ) gene expression in the hypothalamus is developmentally regulated and linked to sexual maturation. Neuron 9:657670.

Ma YJ, Moholt-Siebert M, Hill DF, Ojeda SR (1992b) Regulation of transforming growth factor alpha (TGF $\alpha$ ) mRNA expression in rat hypothalamic astrocytes by TGF $\alpha$ and estradiol $\left(E_{2}\right)$. Soc Neurosci Abstr 18:1449.

Ma YJ, Hill DF, Junier M, Costa ME, Felder SE, Ojeda SR (1994) Expression of epidermal growth factor receptor changes in the hypothalamus during the onset of female puberty. Mol Cell Neurosci, in press.

Martin DL (1992) Synthesis and release of neuroactive substances by glial cells. Glia 5:81-94.

Massague J (1990) Transforming growth factor- $\alpha$. A model for membrane-anchored growth factors. J Biol Chem 265:21393-21396. 
McCarthy KD, de Vellis J (1980) Preparation of separate astroglial and oligodendroglial cell cultures from rat cerebral tissue. J Cell Biol 85:890-902.

Morrison RS, Kornblum HI, Leslie FM, Bradshaw RA (1987) Trophic stimulation of cultured neurons from neonatal rat brain by epidermal growth factor. Science 238:72-74.

Mueller SG, Kobrin MS, Paterson AJ, Kudlow JE (1989) Transforming growth factor- $\alpha$ expression in the anterior pituitary gland: regulation by epidermal growth factor and phorbol ester in dispersed cells. Mol Endocrinol 3:976-983.

Murphy S, Pearce B (1987) Functional receptors for neurotransmitters on astroglial cells. Neuroscience 22:381-394.

Murthy U, Rieman DJ, Rodeck U (1990) Inhibition of TGF $\alpha$-induced second messengers by anti-EGF receptor antibody -425 . Biochem Biophys Res Commun 172:471-476.

Nelson KG, Takahashi T, Lee DC, Luetteke NC, Bossert NL, Ross K, Eitzman BE, McLachlan JA (1992) Transforming growth factor- $\alpha$ is a potential mediator of estrogen action in the mouse uterus. Endocrinology 131:1657-1664.

Nilaver G, Kozlowski GP (1989) Comparison of the PAP and ABC immunocytochemical techniques. In: Techniques in immunocytochemistry, Vol 4 (Bullock GR, Petrusz P, eds), pp 199-215. New York: Academic.

Ojeda SR, Urbanski HF (1988) Intracellular regulatory mechanisms of LHRH secretion and the onset of female puberty. In: Neuroendocrine control of the hypothalamic-pituitary system (Imura $\mathbf{H}$, ed), pp 49-64. Tokyo: Japan Scientific.

Ojeda SR, Urbanski HF, Costa ME, Hill DF, Moholt-Siebert M (1990) Involvement of transforming growth factor $\alpha$ in the release of luteinizing-hormone releasing hormone from the developing female hypothalamus. Proc Natl Acad Sci USA 87:9698-9702.

Peppel K, Baglioni C (1990) A simple and fast method to extract RNA from tissue culture cells. Biotechniques 9:711-713.

Petch LA, Harris J, Raymond VW, Blasband A, Les DC, Earp HS (1990) A truncated, secreted form of the epidermal growth factor receptor is encoded by an alternatively spliced transcript in normal rat tissue. Mol Cell Biol 10:2973-2982.

Pfaff DW, Keiner M (1973) Atlas of estradiol-concentrating cells in the central nervous system of the female rat. J Comp Neurol 151: 121-158.

Pittelkow MR, Lindquist PB, Abraham RT, Graves-Deal R, Derynck $\mathrm{R}$, Coffey RJ Jr (1989) Induction of transforming growth factor- $\alpha$ expression in human keratinocytes by phorbol esters. J Biol Chem 264:5164-5171.
Pons S, Torres-Aleman I (1992) Basic fibroblast growth factor modulates insulin-like growth factor-I, its receptor, and its binding proteins in hypothalamic cell cultures. Endocrinology 131:2271-2278.

Pons S, Torres-Aleman I (1993) Estradiol modulates insulin-like growth factor I receptors and binding proteins in neurons from the hypothalamus. J Neuroendocrinol 5:267-271.

Saeki T, Cristiano A, Lynch MJ, Brattain M, Kim N, Normanno N, Kenney N (1991) Regulation by estrogen through the 5 '-flanking region of the transforming growth factor $\alpha$ gene. Mol Endocrinol 5: $1955-1963$.

Saneto RP, de Vellis J (1987) Neuronal and glial cells: cell culture of the central nervous system. In: Neurochemistry - a practical approach (Turner AJ, Bachelard HS, eds), pp 27-63. Washington, DC: IRL.

Shinoda H, Marini AM, Cosi C, Schwartz JP (1989) Brain region and gene specificity of neuropeptide gene expression in cultured astrocytes. Science 245:415-417.

Sinner MK, Coffey RJ, Jr (1988) Regulation of ovarian cell growth through the local production of transforming growth factor- $\alpha$ by theca cells. Endocrinology 123:2632-2638.

Spranger M, Lindholm D, Bandtlow C, Heumann R, Gnahn H, NäherNoé M, Thoenen H (1990) Regulation of nerve growth factor (NGF) synthesis in the rat central nervous system: comparison between the effects of interleukin- 1 and various growth factors in astrocyte cultures and in vivo. Fur J Neurosci 2:69-76.

Steward O, Torre ER, Tomasulo R, Lothman E (1991) Neuronal activity up-regulates astroglial gene expression. Proc Natl Acad Sci USA 88:6819-6823.

Stornetta RL, Hawelu-Johnson CL, Guyenet PG, Lynch KR (1988) Astrocytes synthesize angiotensinogen in brain. Science 242:1444 1446.

Toran-Allerand CD, Ellis L, Pfenninger KH (1988) Estrogen and insulin synergism in neurite growth enhancement in vitro: mediation of steroid effects by interaction with growth factors? Dev Brain Res 41:87-100.

Wang S, Shiverick KT, Ogilvie S, Dunn WA, Raizada MK (1989) Characterization of epidermal growth factor receptors in astrocytic glial and neuronal cells in primary culture. Endocrinology 124:240247.

Wilcox JN, Derynck R (1988) Localization of cells synthesizing transforming growth factor-alpha mRNA in the mouse brain. J Neurosci 8:1901-1904

Yaish P, Gazit A, Gilon C, Levitzki A (1988) Blocking of EGF-dependent cell proliferation by EGF receptor kinase inhibitors. Science 242:933-935. 